\title{
Groundwater Resources of the Columbia Plateau Regional Aquifer System
}

\section{What Is the Columbia Plateau?}

The Columbia Plateau is a wide basalt plateau between the Cascade Range and the Rocky Mountains that covers parts of Washington, Oregon, and Idaho (fig. 1). The climate over much of the Columbia Plateau is semiarid with precipitation ranging from 7 to $15 \mathrm{in} / \mathrm{yr}$ in the central part (Vaccaro and others, 2015), yet the area supports a $\$ 6$ billion per year agricultural industry, including the production of apples, corn, grapes, hops, mint, potatoes, stone fruit, and wheat. Groundwater pumpage and surface-water diversions supply water to irrigated croplands that account for about 5 percent of the Nation's irrigated lands. Groundwater also is the primary source of drinking water for about 1.3 million people living on the plateau.

\section{What Is the USGS Columbia Plateau Groundwater Availability Study?}

The U.S. Geological Survey (USGS) conducts large-scale multidisciplinary regional studies of groundwater availability, such as this study of the Columbia Plateau Regional Aquifer System (CPRAS). This study provides citizens, communities, and natural resource managers with (1) improved information and knowledge of the status of the groundwater resources,

(2) information about how the resources have changed over time, and (3) tools to forecast how the resources may change in the future.

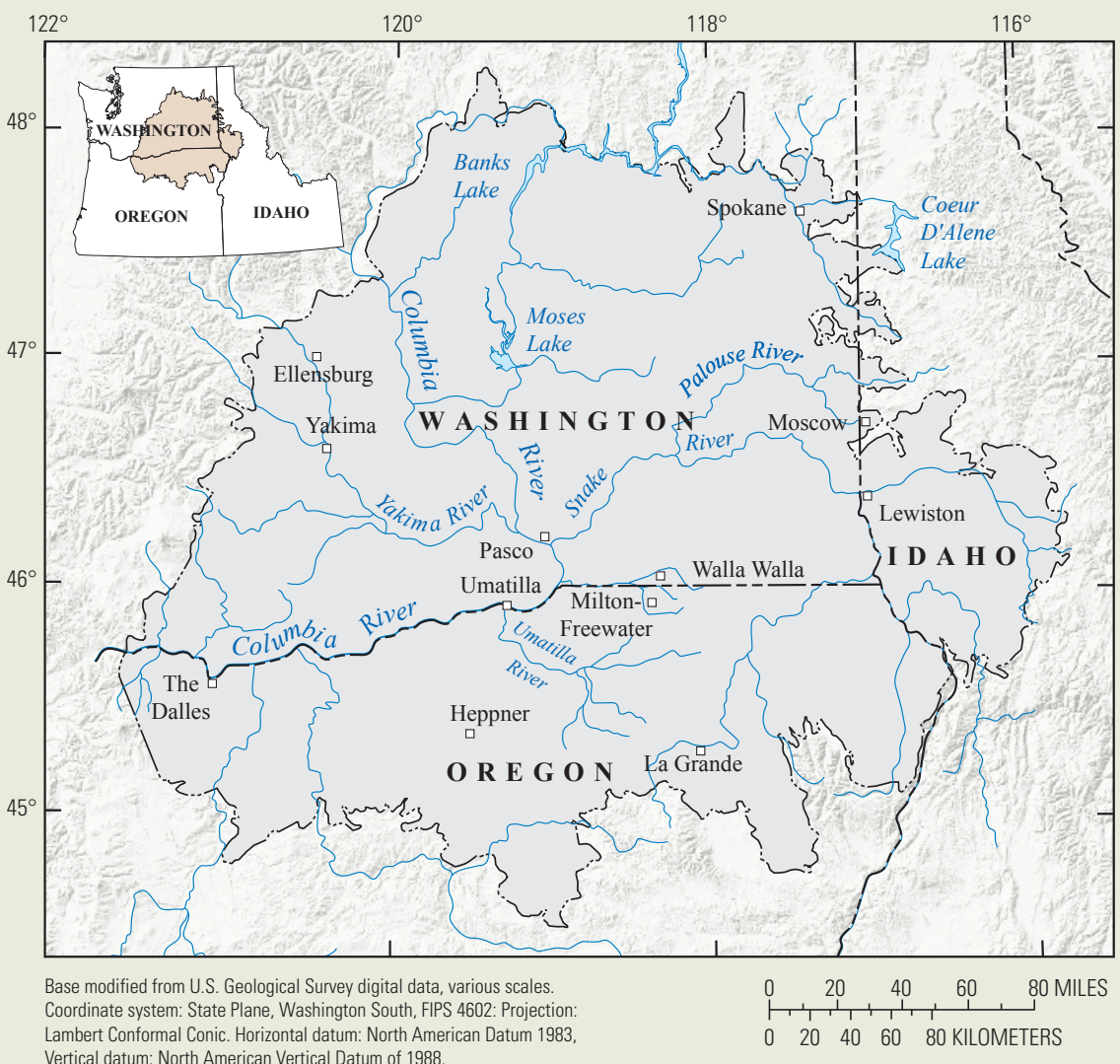

Figure 1. Columbia Plateau Regional Aquifer System study area, Washington, Oregon, and Idaho.

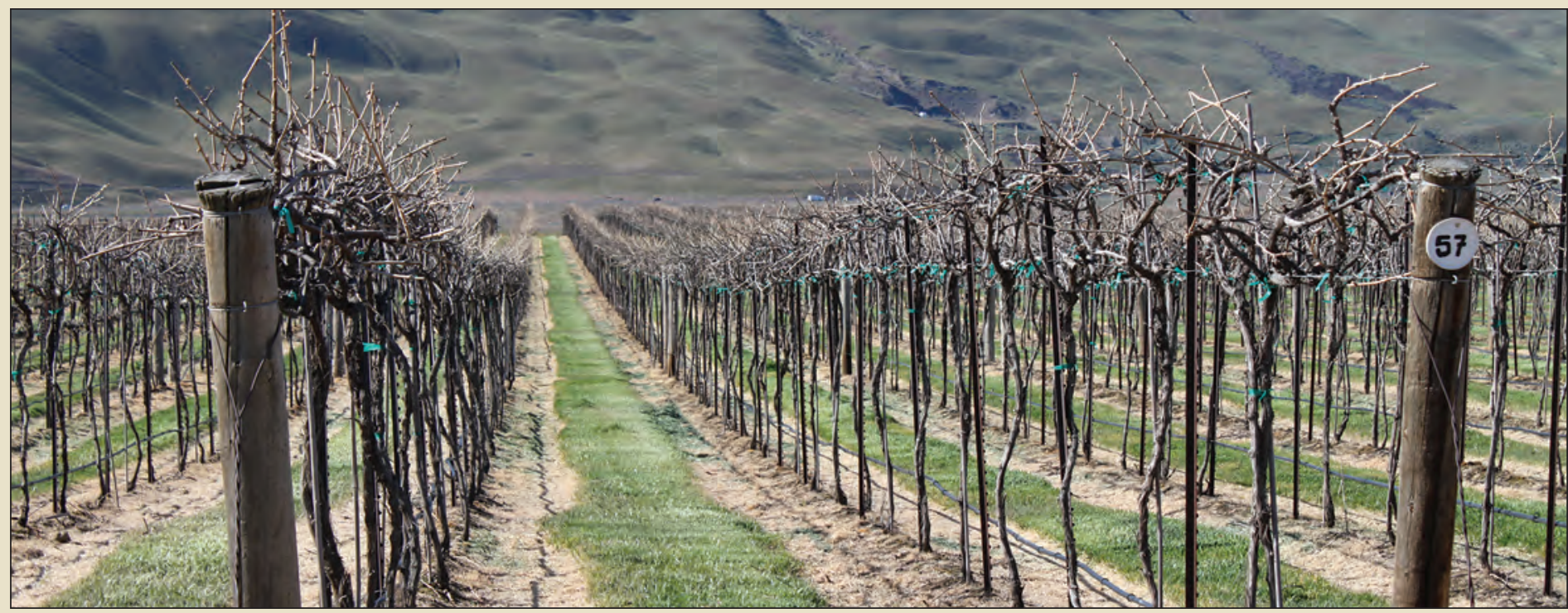

Vineyard looking (south) toward Horse Heaven Hills, Washington. Photograph by Carmen Lee, 2011. 


\section{What Is the Columbia Plateau Regional Aquifer System?}

The CPRAS covers an area of about 44,000 square miles within the drainage of the Columbia River. The primary aquifers within the Columbia Plateau occur in basalts of the Columbia River Basalt Group (CRBG) and in places, overlying sediment. The CRBG consists of a series of lava flows that erupted from fissures and vents along the Washington/Oregon/Idaho border during the Miocene Age, 17 million to 6 million years ago. More than 350 flows have been identified and individual flows range in thickness from 10 to more than 300 feet; interbeds occur in places where sediment accumulated between flows.

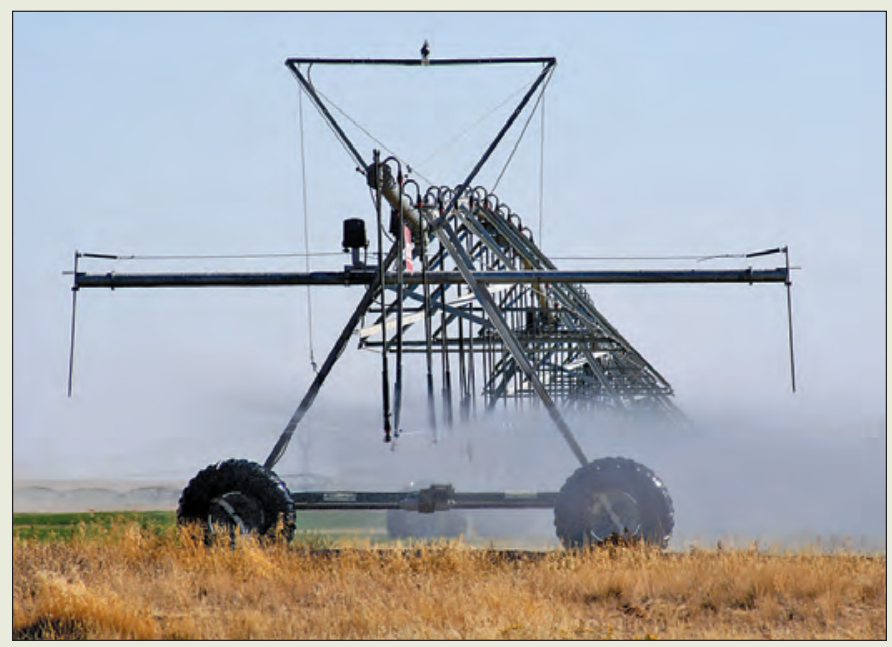

Pivot irrigator, northeastern Washington. Photograph by David Beedon, 2003.

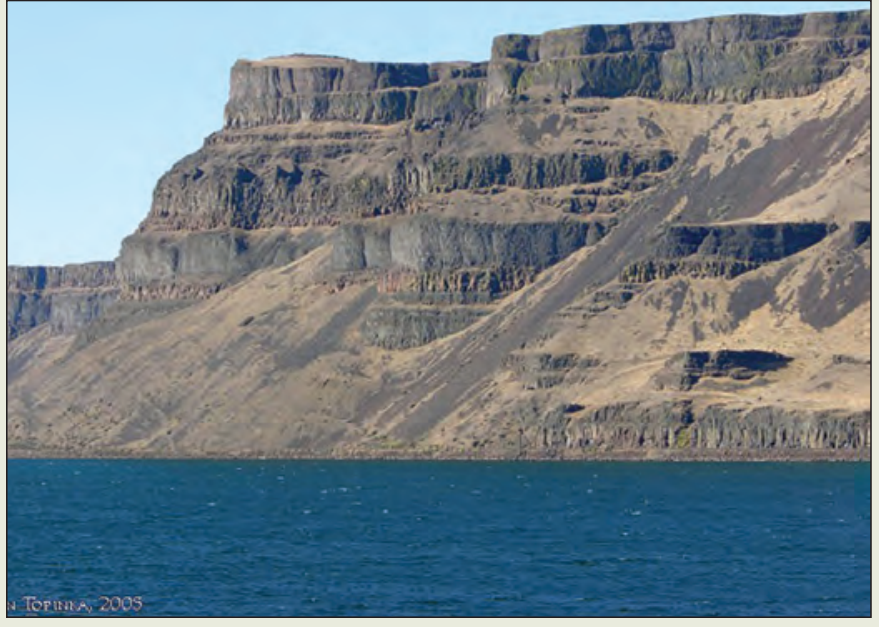

Basalt bluffs at Wallula Gap, Washington. Photograph by Lyn Topinka, U.S. Geological Survey, 2005.

Groundwater levels have declined over more than 10,000 square miles (about 23 percent of the CPRAS) due to pumping at rates that exceed groundwater recharge. Areas with large and widespread declines are located in the central northern part of the study area (referred to as the Odessa Subarea), in parts of the Yakima River basin in Washington, in the Pullman-Moscow area in Washington and Idaho, and in parts of the Umatilla River basin in Oregon. These declines are in areas known to rely heavily on groundwater for irrigation and other uses. In contrast, about 5 percent of the CPRAS has experienced groundwater level rises due to the delivery and application of surface water for irrigation within the large Bureau of Reclamation irrigation projects (fig. 2).

\section{What Kinds of Scientific Information Were Collected and Analyzed?}

Many types of information were collected and analyzed as part of the CPRAS Study, some highlights are:

- Groundwater levels were measured in 1,752 wells during spring 2009 by the USGS and 10 other Federal, State, Tribal, and local agencies (Snyder and Haynes, 2010). This information was used to map the generalized groundwater elevations for the CPRAS and to provide information on regional groundwater flow directions. Groundwater levels measured in 2009 in 470 wells also were compared to groundwater levels measured 25 years earlier in spring 1984. Water levels declined in 83 percent of the measured wells, and declines greater than 25 feet were measured in 29 percent of the wells.

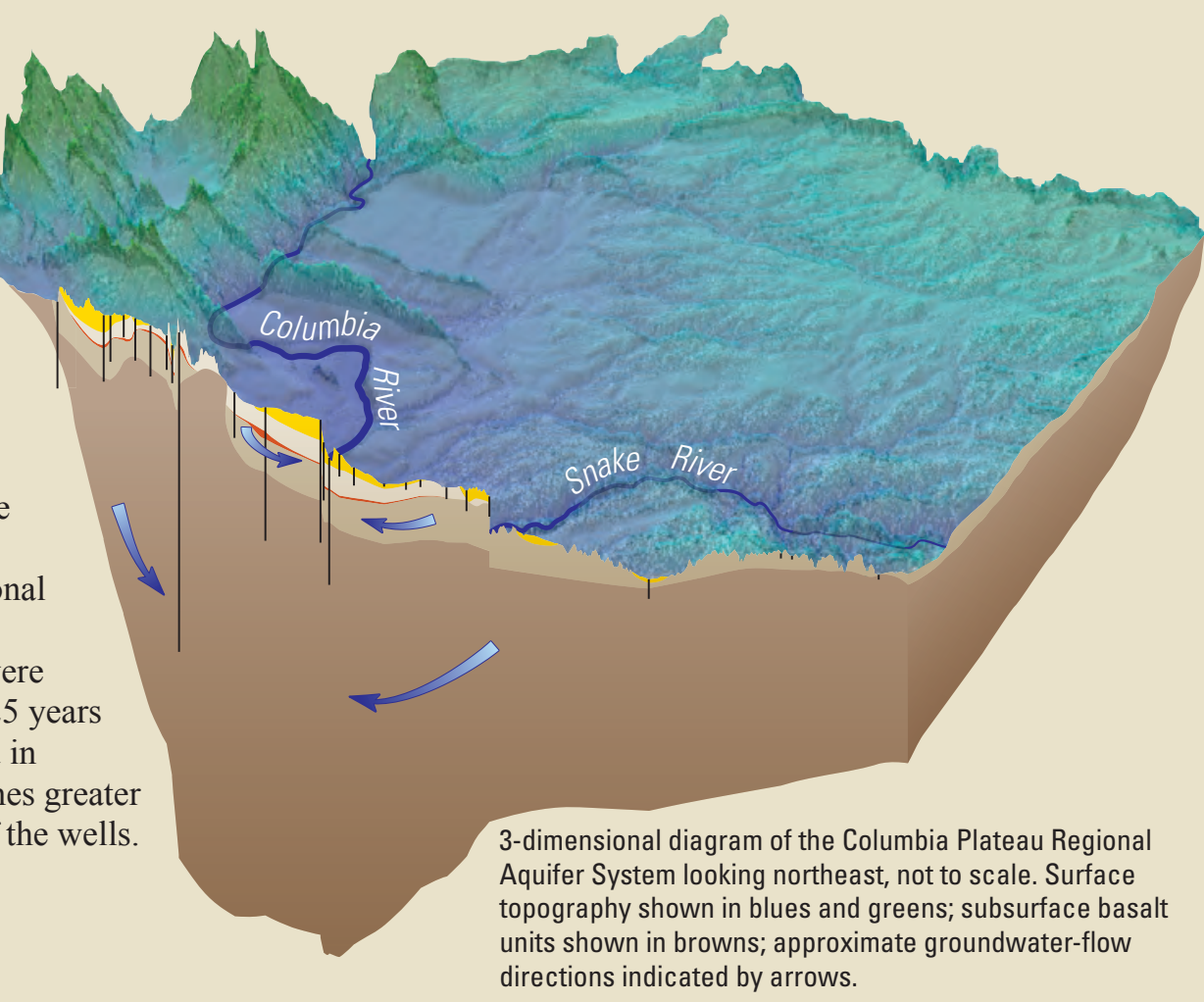



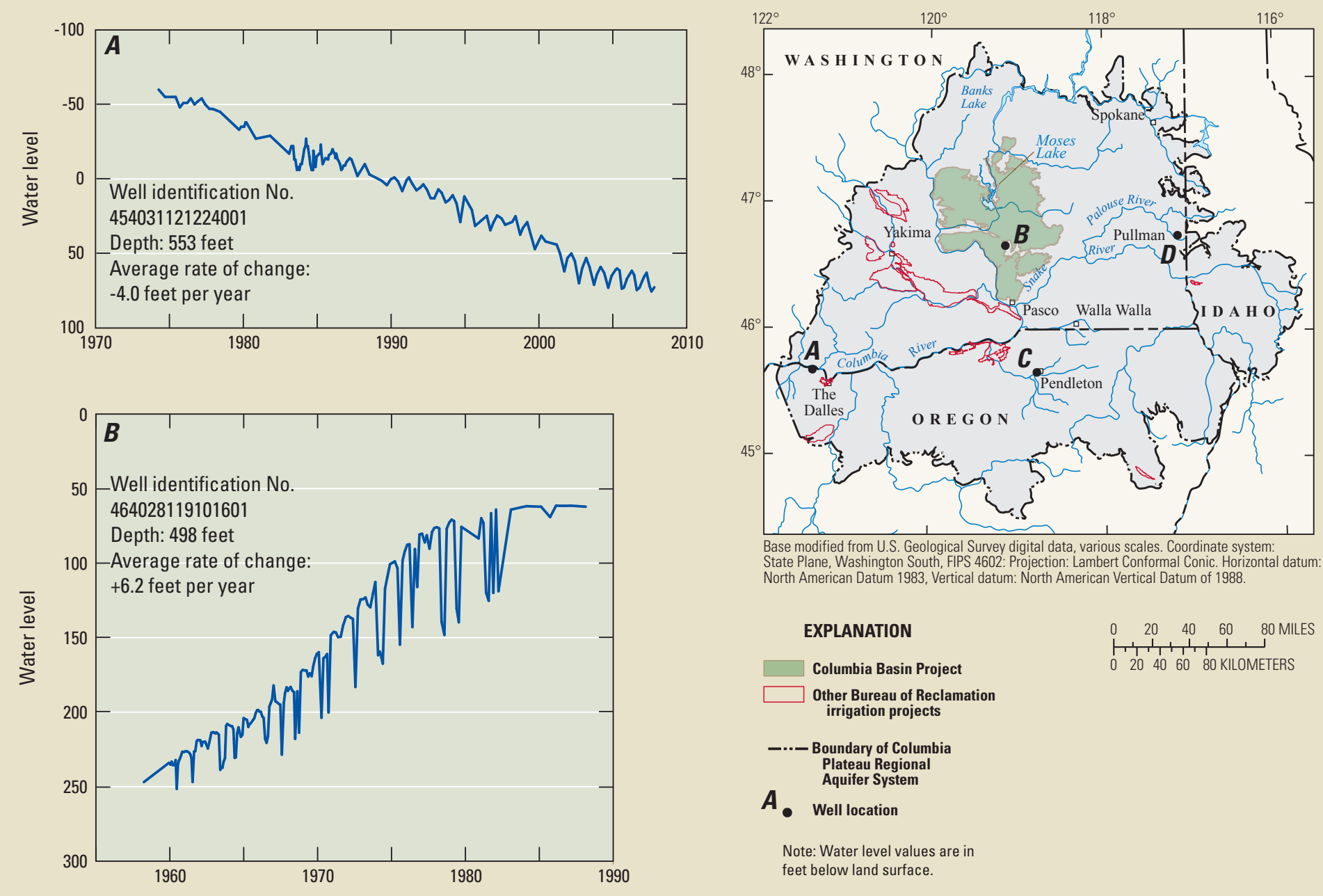

Note: Water level values are in feet below land surface.
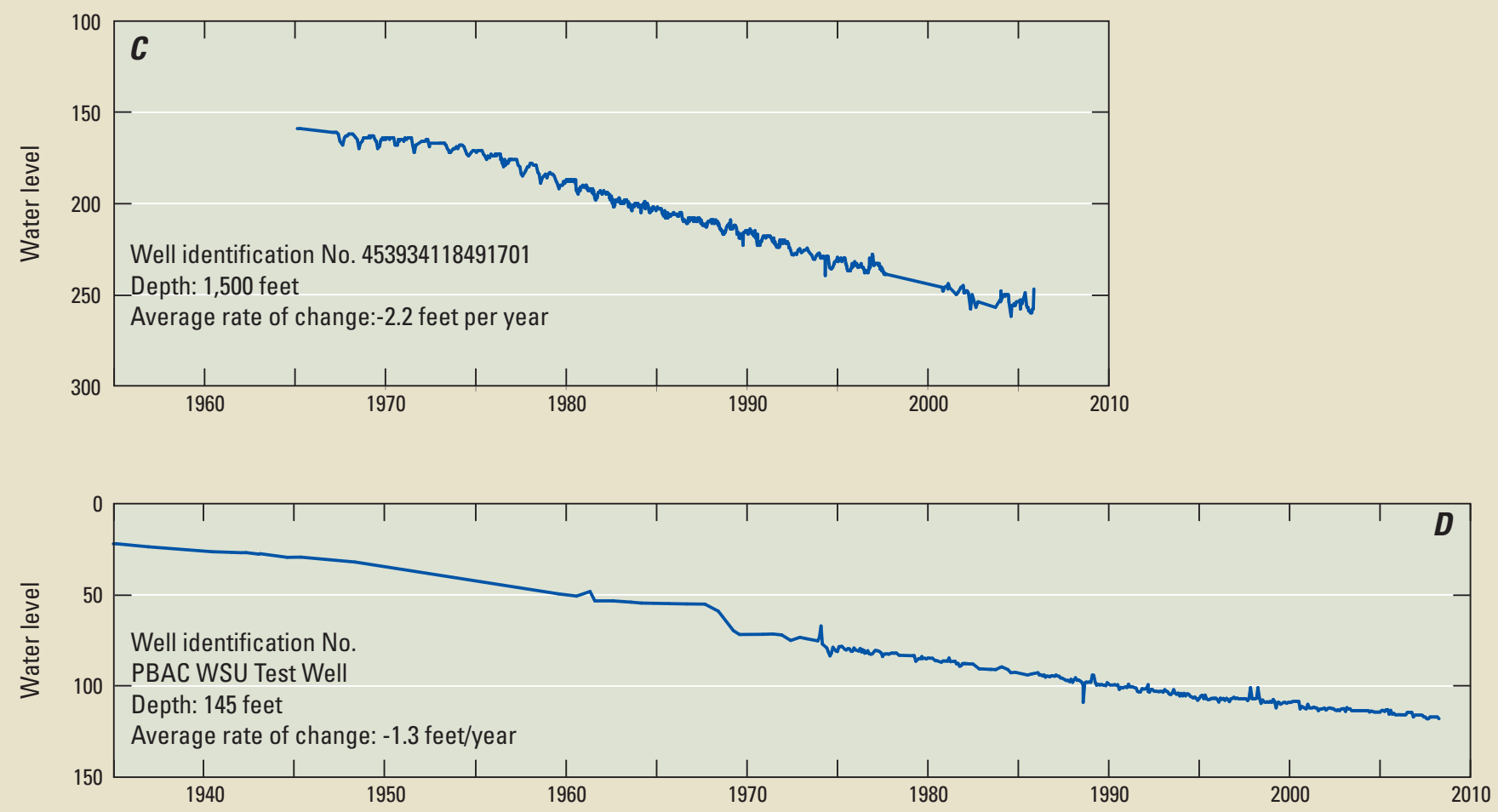

Figure 2. Long-term water level changes in selected wells, Columbia Plateau Regional Aquifer System, Washington, Oregon, and Idaho. All hydrographs are at same scale. (Modified from Snyder and Haynes, 2010.) 
- A digital 3-dimensional geologic model was constructed for the CPRAS to define the general aquifer system geometry (Burns and others, 2011) for use in the regional numerical groundwater-flow model. Data for 13,226 wells were used to construct digital surfaces that represent upper and lower subsurface unit boundaries. A web interface tool was developed to allow users to explore the 3D geologic framework of the CPRAS by drawing diagrams of 'well logs' at any site, or by developing geologic cross sections between multiple sites (http://or.water.usgs.gov/proj/cpras/ index.html).

- A new Simplified Surface Energy Balance (SSEB) method that uses satellite data was developed to estimate monthly evapotranspiration (ET) (Senay and others, 2007, 2008; Kahle and others, 2011). ET is a large component of the water budget; it can account for 100 percent of the annual precipitation in the arid areas and 45-70 percent in the more humid uplands, and historically, had not been estimated.

- A spatially distributed soil-water balance model was developed to use relations among climate, soils, land cover, and irrigation data to compute monthly irrigation requirements and surplus moisture available for groundwater recharge in irrigated areas (Kahle and others, 2011). Estimates of groundwater pumpage and surfacewater diversions needed for irrigation and groundwater recharge resulting from irrigation were then calculated with ET from the SSEB driving the calculations.

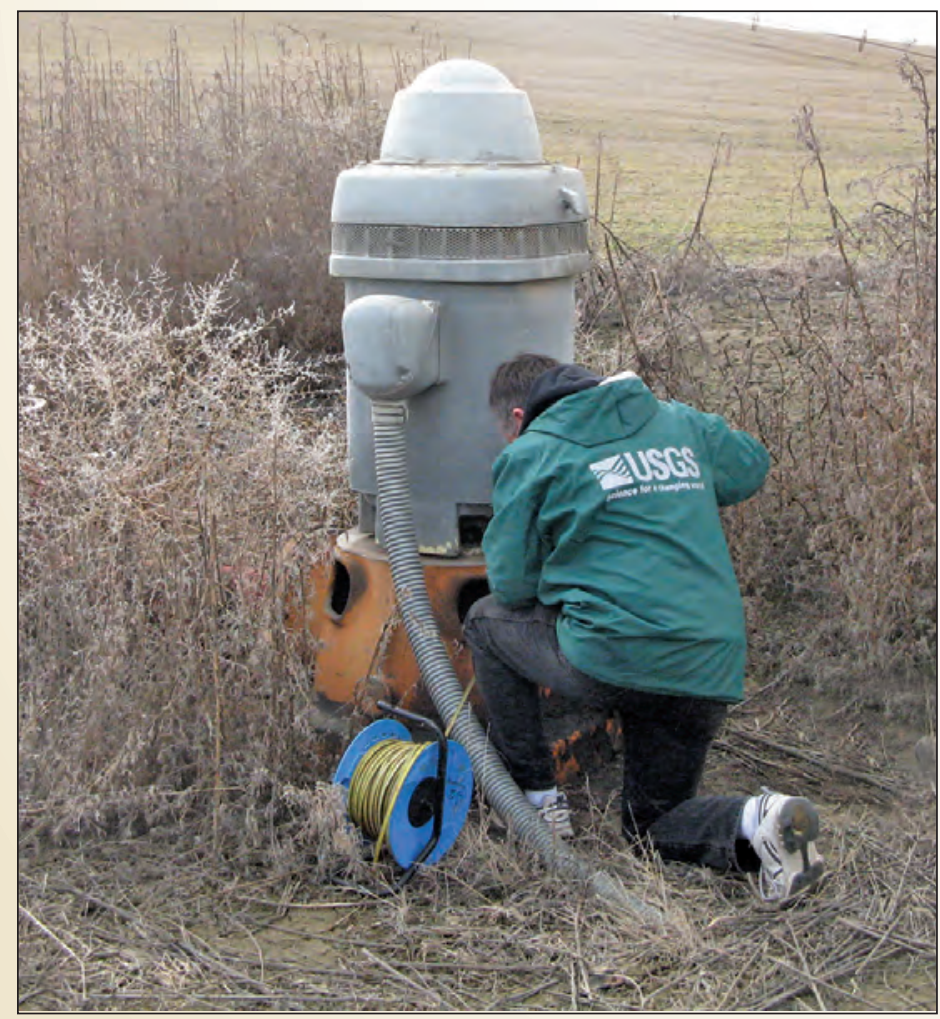

USGS hydrologic technician measuring the water level in a well near Yakima. Photograph by Karen Payne, U.S. Geological Survey, March 2009.

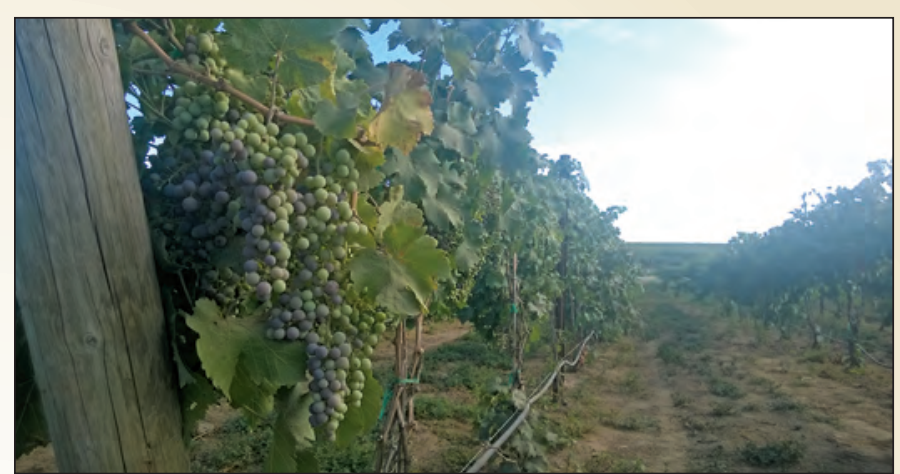

Wine grapes near George, Washington. Photograph by Pearl Kahle, 2015.

\section{What Is the Groundwater-Flow Model of the System?}

A major product of this assessment is a numerical groundwater-flow model of the CPRAS (Ely and others, 2014). A groundwater-flow model is a mathematical representation of groundwater flow through an aquifer system that uses information about aquifer properties, groundwater recharge, discharge, and groundwater levels, as well as physical processes governing groundwater flow. Models are useful tools for investigating variations in water supply, water demand, management strategies, groundwater/ surface-water exchanges, and potential effects of changing climate on a hydrologic system.

The CPRAS model domain was subdivided into a horizontal grid of 126 rows and 131 columns using a uniform 3-kilometer (9,842-feet) grid. Each of the five hydrogeologic units represented in the model was subdivided into approximately 100 -foot-thick layers, yielding 100 model layers. The detailed vertical discretization improved the understanding of the important vertical flow component in the CPRAS.

The model was used to estimate annual water budgets for the system, flow between hydrogeologic units, changes in the system from predevelopment conditions, likely changes in the system if the conditions in 2007 existed through 2050, and potential effects in 2050 of increased irrigation demand owing to climate warming. The model results show the potential usefulness of this tool in providing information for short- to long-term management planning and decisions by numerous stakeholders.

Among the important findings of this new groundwater-flow model of the CPRAS are:

- The use of many thin layers improves representation of vertical groundwater gradients and connectivity with surface-water features.

- Groundwater pumping has increased substantially since the 1970s-1980s and this increase has resulted in declining water levels at depth and decreasing stream base flows over much of the study area; and

- During dry to average precipitation years, groundwater pumping causes a net loss of groundwater in storage. Groundwater pumping presently exceeds groundwater recharge during all but the wettest of years. 


\section{What Are the Key Points Regarding Water Resources?}

Groundwater availability is critical to managing water resources in the CPRAS because of the high water demand for agriculture, economic development, and ecological needs and the great competition for the limited resource. Waterresource issues that have implications for future groundwater availability include:

- Widespread water-level declines associated with development of groundwater resources for irrigation and other uses;

- Decrease in base flow to rivers and associated effects on water temperature and quality;

- Limited availability of non-appropriated surface water;

- Potential capture of surface water, which was appropriated through senior water rights by pumpage of groundwater, which was appropriated through junior water rights; and

- Current and projected effects of climate change and variability on increasing pumping demand, groundwater recharge, base flow in rivers, and ultimately, sustainable groundwater yields.

Ongoing activities in the region for enhancement of fisheries and obtaining additional water for agricultural, municipal, and domestic use may be affected by groundwater withdrawals and rules implemented under the Endangered Species Act for numerous stocks of salmonids. The study addressed some of these groundwater availability issues by improving the understanding of the hydrogeologic system, the status and trends of the groundwater system, the general relation between groundwater and surface waters, current water use, and the water budget for the CPRAS.

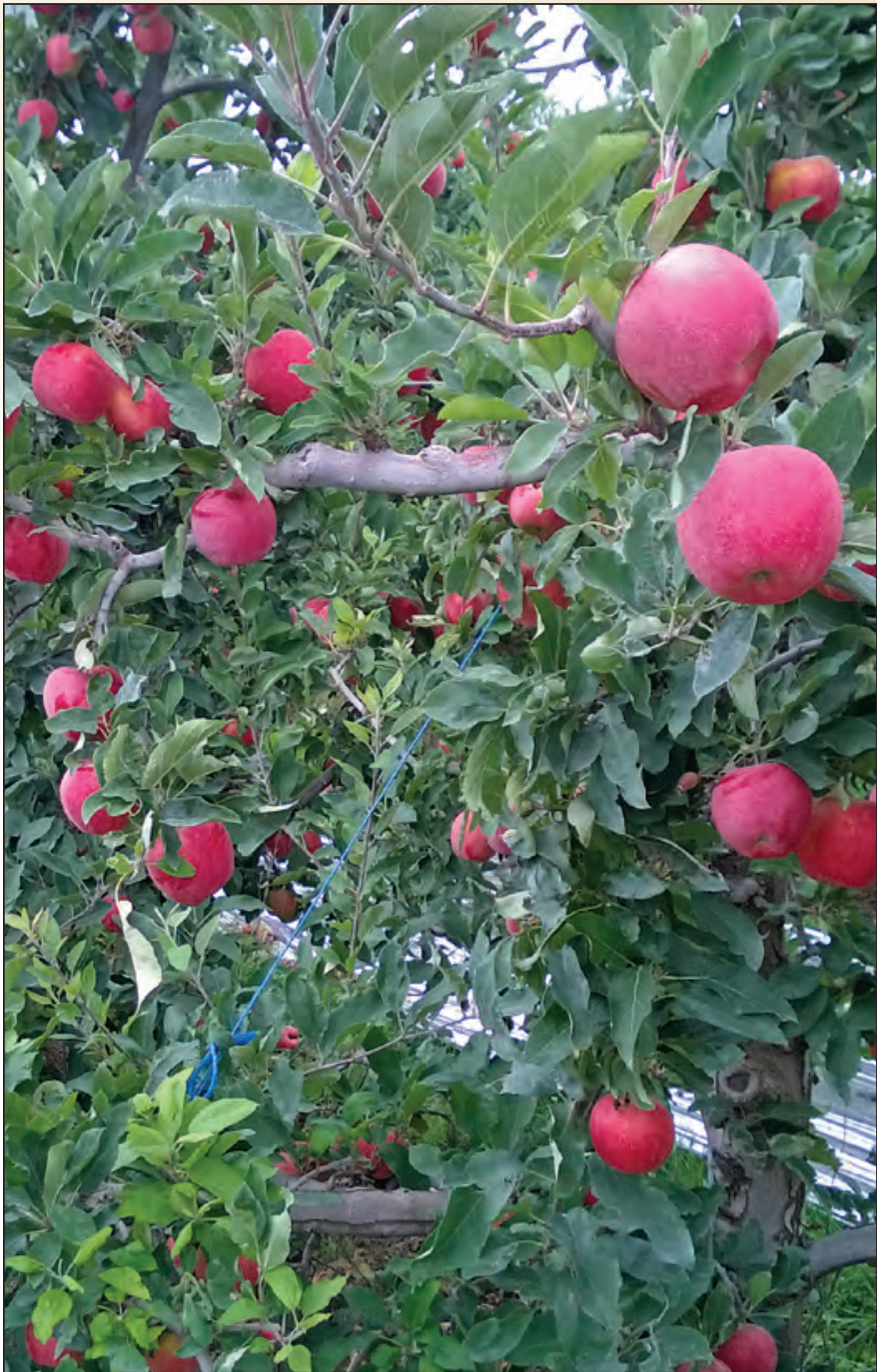

Fuji apples east of Moses Lake, Washington. Photograph by Sue Kahle, 2015.

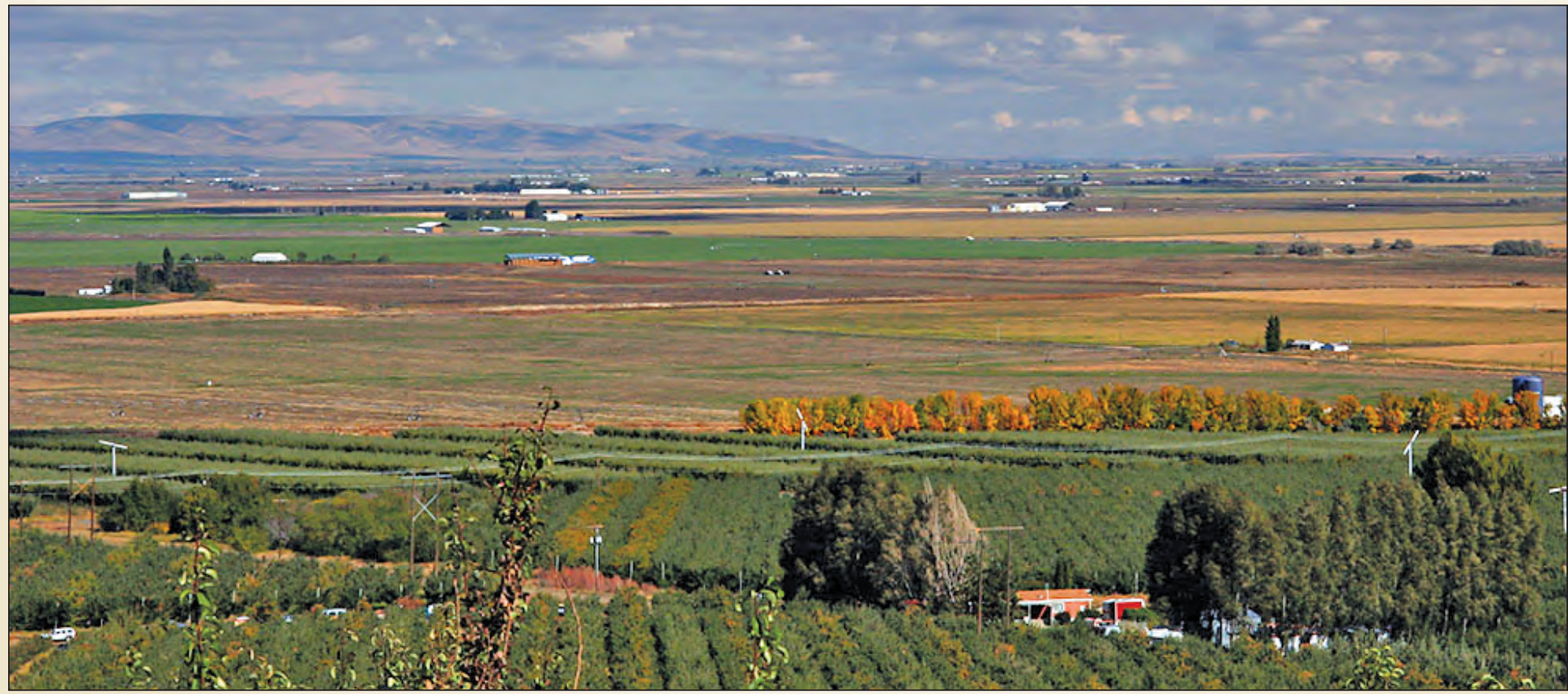

Agriculture in the Quincy Valley. Photograph by David Putnam, July 2006. 


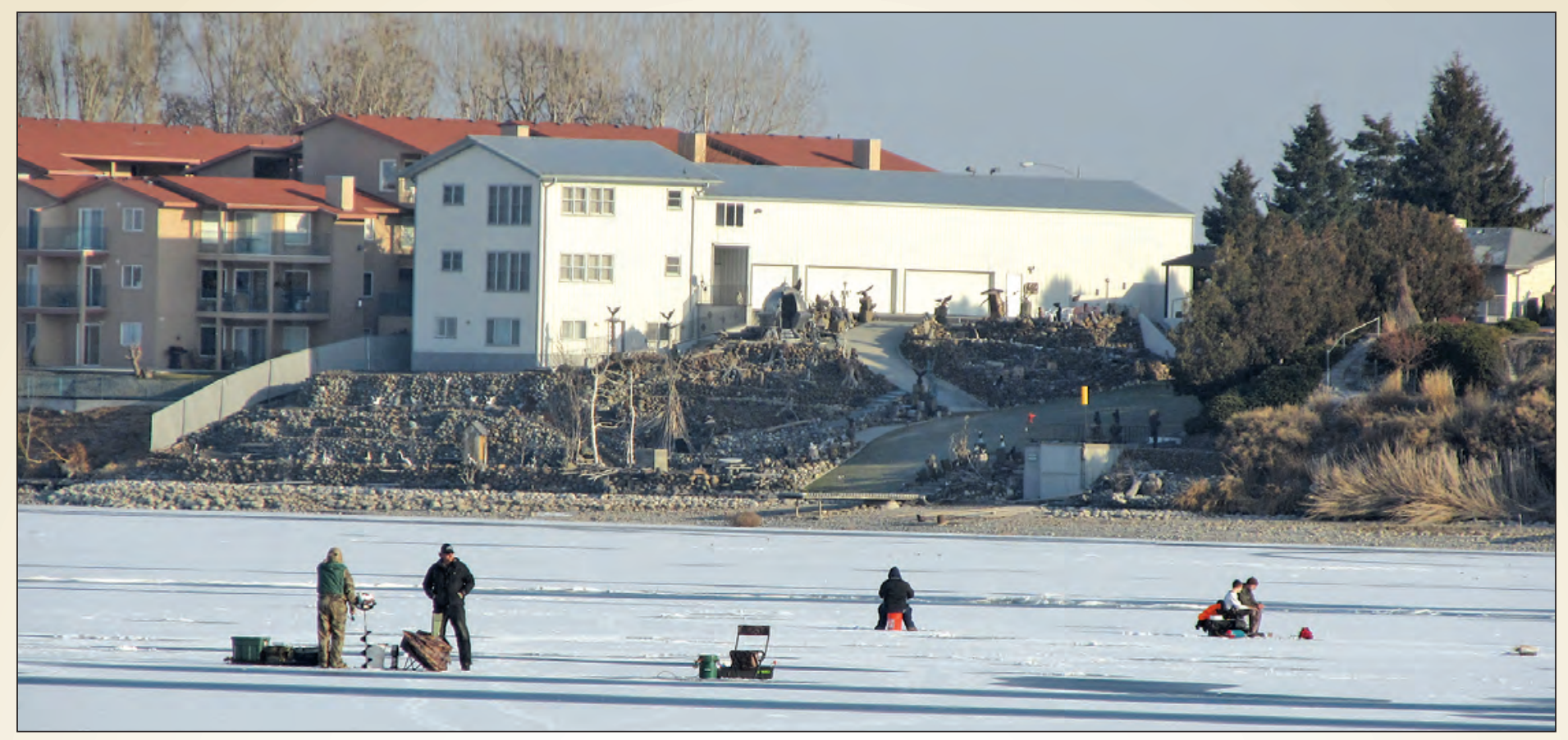

Ice fishing on Moses Lake, Washington. Photograph by Karen Payne, U.S. Geological Survey, 2011.

\section{Additional Information}

This USGS Fact Sheet is a brief summary of USGS Professional Paper 1817, "Groundwater availability of the Columbia Plateau Regional Aquifer System, Washington, Oregon, and Idaho" by J.J. Vaccaro, S.C. Kahle, D.M. Ely, E.R. Burns, D.T. Snyder, J.V. Haynes, T.D. Olsen, W.B. Welch, and D.S. Morgan. For additional information regarding this study, readers are referred to the Professional Paper for more in-depth descriptions of the CPRAS study and results of the investigation.

\section{References Cited}

Burns, E.R., Morgan, D.S., Peavler, R.S., and Kahle, S.C., 2011, Three-dimensional model of the geologic framework for the Columbia Plateau Regional Aquifer System, Idaho, Oregon, and Washington: U.S. Geological Survey Scientific Investigations Report 2010-5246, 44 p., accessed March 1, 2011, at http://pubs. usgs.gov/sir/2010/5246/.

Ely, D.M., Burns, E.R., Morgan, D.S., and Vaccaro, J.J., 2014, Numerical simulation of groundwater flow in the Columbia Plateau Regional Aquifer System, Idaho, Oregon, and Washington: U.S. Geological Survey Scientific Investigations Report 2014-5127, 90 p., http://dx.doi.org/10.3133/sir20145127.

Kahle, S.C., Morgan, D.S., and Welch, W.B., 2011, Hydrogeologic framework and hydrologic budget components of the Columbia Plateau Regional Aquifer System, Washington, Oregon, and Idaho: U.S. Geological Survey Scientific Investigations Report 2011-5124, 66 p., accessed August 26, 2011, at http://pubs.usgs. gov/sir/2011/5124/.

Senay, G.B., Budde, M.E., Verdin, J.P., and Melesse, A.M., 2007, A coupled remote sensing and simplified surface energy balance approach to estimate actual evapotranspiration from irrigated fields: Sensors, v. 7, p. 979-1,000.
Senay, G.B, Verdin, J.P., Lietzow, R., and Melesse, A.M., 2008, Global reference evapotranspiration modeling and evaluation: Journal of American Water Resources Association, v. 44, no. 4, p. 969-979.

Snyder, D.T., and Haynes, J.V., 2010, Groundwater conditions during 2009 and changes in groundwater levels from 1984 to 2009, Columbia Plateau Regional Aquifer System, Washington, Oregon, and Idaho: U.S. Geological Survey Scientific Investigations Report 2010-5040, 12 p., accessed October 27, 2010, at http://pubs.usgs.gov/sir/2010/5040/.

Vaccaro, J.J., Kahle, S.C., Ely, D.M., Burns, E.R., Snyder, D.T., Haynes, J.V., Olsen, T.D., Welch, W.B., and Morgan, D.S., 2015, Groundwater availability of the Columbia Plateau Regional Aquifer System, Washington, Oregon, and Idaho: U.S. Geological Survey Professional Paper 1817, 87 p., http://dx.doi. org/10.3133/pp1817.

Authors: Sue C. Kahle and John J. Vaccaro

For more information:

Director, Washington Water Science Center

U.S.Geological Survey

934 Broadway, Suite 300

Tacoma, Washington 98402

http://wa.water.usgs.gov/

Project web page at:

http://wa.water.usgs.gov/projects/cpgw/

Publishing support provided by the

U.S. Geological Survey,

Science Publishing Network,

Tacoma Publishing Service Center

ISSN 2327-6932 (online)

ISSN 2327-6916 (print)

http://dx.doi.org/10.3133/fs20153063 